\title{
Immunity and immunopathology in early human life
}

\author{
Tobias R. Kollmann ${ }^{1} \cdot$ Arnaud Marchant $^{2}$
}

Received: 9 October 2017 / Accepted: 9 October 2017 /Published online: 23 November 2017

(C) Springer-Verlag GmbH Germany 2017

This special issue, "Immunocompetence of the Newborn", is focused on the induction and regulation of immune responses in early life, because recent studies of early life immune ontogeny call into question the prevailing view of an immature newborn immune system.

Infectious disease cause nearly one third of all neonatal deaths; in addition, a large proportion of stillbirths are presumed to be related to an infectious insult of the maternalfetal dyad [1]. This harsh clinical reality of an increased risk to suffer from infection in early life has historically been explained as the consequence of an "immaturity" of the fetal or neonatal immune system [2]. Over the years, this "immaturity" has most often been interpreted to imply that the immune system in fetal or neonatal stages of development was less able to develop effector responses than in the adult and much of the experimental data published over the last five decades appeared to support this notion [3]. However, reports of increased immune responses in the newborn also appeared over the years, challenging the prevailing view of generally lower immune responsiveness in early life [4]. Reconciliation of these apparently contradicting findings has more recently

This article is a contribution to the special issue on Immunocompetence of the Newborn - Guest Editors: Arnaud Marchant and Tobias Kollmann

Tobias R. Kollmann

tkollm@mac.com

Arnaud Marchant

arnaud.marchant@ulb.ac.be

1 Division of Infectious Diseases, Department of Pediatrics, University of British Columbia, Vancouver, BC, Canada

2 Institute for Medical Immunology, Université libre de Bruxelles, Charleroi, Belgium been achieved through the recognition that the fetal and newborn immune system is not simply less responsive, but functionally different from that of an adult, and that these differences reflect age-dependent differences in the demands $[5,6]$. However, this new insight now begs to answer the question: If the fetus or newborn is capable of adult-like immune responses, why do they clinically suffer more readily from infectious insults? This special edition explores one possible answer: The fetus and newborn may suffer more readily from infection because their immune system responds not less but more than that of an adult, and in that stronger response appears more prone to do so in a host-damaging way (immunemediated pathology).

In this special edition of Seminars in Immunopathology, Raz Somech's group reviews the evidence that $\mathrm{T}$ as well as B cell repertoires begin to diversify in fetal life already [7]. The concept of functional fetal adaptive immune responses is further explored by the group around Richard Lo-Man, presenting evidence of in utero development of memory $\mathrm{T}$ cells [8], while Donna Farber and colleagues place this early life T cell development into the context of tissue compartmentalization [9]. These pre-natal immune events clearly do not happen in isolation, but are modulated by the maternal immune system, as reviewed by Arnaud Marchant's group [10]. The impact of such pre- and perinatal events on neonatal infection then is examined by Tobias Kollmann's team [11], while Beate Kampmann and colleagues focus on this impact in regard to neonatal vaccination [12]. A particularly useful example for an evolutionary selection of age-dependent, advantageous response patterns is presented by Antonio Bertoletti and colleague in the case of hepatitis B infection around birth [13]. Furthermore, the events occurring before or during birth profoundly impact not only the acute response to infection or vaccination but also the immune ontogeny with clinical ramifications for years to come; specifically, with respect to the onset of type 1 diabetes, as reviewed 
by Mikael Knip and colleagues [14], as well as allergies, as discussed by Peter Vuillermin's review [15].

Following the common thread woven through these cutting-edge reviews, a tapestry emerges that presents the fetus and newborn not as immature but as highly immune-responsive, ready to adapt to the particular functional demands they are faced with. This tapestry is presented on the front cover of this issue (a newborn baby towering dangerously high on stilts made of maternal antibodies, on the backdrop of a beautiful sky). Specifically, one of the most peculiar demands in early life is to balance risk/benefit of an immune response to danger while maintaining immune homeostasis at the semiallogeneic maternal-fetal interphase; as a result, the threshold to unleash an immune effector response is set very high (the baby is thus on very high stilts). However, once this threshold is reached, the risk of unleashing host-damaging immune responses is substantial (a fall from stilts is higher relative to that of an adult standing on legs) [16]. Thus, the increased risk to suffer and die from infection relates to the higher immune-cost of effector responses in early vs. adult life (the precarious, unsteady balancing act of the baby in our picture) [17]. This difficult situation is somewhat stabilized by the provision of maternal immunity (symbolized in our picture as antibody-stilts), that allow the baby to look up and ahead into a bright future (the blue sky in our picture).

\section{References}

1. Maldonado YA, Nizet V, Klein JO, Remington JS, Wilson CB (2016) In: Nizet V, Wilson CB, Maldonado Y, Remington JS, Klein JO (eds) Infectious diseases of the fetus and newborn infant, 8th edn. Elsevier Saunders, Philadelphia, pp 3-23

2. Sterzl J, Silverstein AM (1967) Developmental aspects of immunity. Adv Immunol 6:337-459

3. Simon AK, Hollander GA, McMichael A (2015) Evolution of the immune system in humans from infancy to old age. Proc Biol Sci 282:20143085
4. Hong DK, LD (2016) In:Nizet V, Wilson CB, Maldonado Y, Remington JS, Klein JO (eds) Infectious diseases of the fetus and newborn infant, 8 Edn. Elsevier Saunders, Philadelphia, pp 81-188

5. Kollmann TR, Kampmann B, Mazmanian SK, Marchant A, Levy O (2017) Protecting the newborn and young infant from infectious diseases: lessons from immune ontogeny. Immunity 46:350363

6. Zhang X, Zhivaki D, Lo-Man R (2017) Unique aspects of the perinatal immune system. Nat Rev

7. Rechavi E, Somech R (2017) Survival of the fetus-fetal B and T cell receptor 5 repertoire development. Semin Immunopathol. https://doi.org/10.1007/s00281-017-0626-0

8. Zhivaki D, Lo-Man R (2017) In utero development of memory T cells. Semin Immunopathol. https://doi.org/10.1007/s00281-0170650-0

9. Zens KD, Connors T, Farber DL (2017) Tissue compartmentalization of $\mathrm{T}$ cell responses during early life. Semin Immunopathol. https://doi.org/10.1007/s00281-017-0648-7

10. Jennewein MF, Abu-Raya B, Jiang Y, Alter G, Marchant A (2017) Transfer of maternal immunity and programming of the newborn immune system. Semin Immunopathol. https://doi.org/10.1007/ s00281-017-0653-x

11. Brook B, Harbeson D, Ben-Othman R, Viemann D, Kollmann TR (2017) Newborn susceptibility to infection vs. disease depends 5 on complex in vivo interactions of host and pathogen. Semin Immunopathol. https://doi.org/10.1007/s00281-017-0651-z

12. Saso A, Kampmann B (2017) Vaccine responses in newborns. Semin Immunopathol. https://doi.org/10.1007/s00281-017-0654-9

13. Hong M, Bertoletti A (2017) Tolerance and immunity to pathogens in early life - insights from HBV infection. Semin Immunopathol. https://doi.org/10.1007/s00281-017-0641-1

14. Knip M, Luopajärvi K, Härkönen T (2017) Early life origin of type 1 diabetes. Semin Immunopathol. https://doi.org/10.1007/s00281017-0665-6

15. Vuillermin P, Macia L, Nanan R, Tang M, Collier F, Brix S (2017) The maternal microbiome during pregnancy and allergic disease in the offspring. Semin Immunopathol. https://doi.org/10.1007/ s00281-017-0652-y

16. Ghazal P, Dickinson P, Smith CL (2013) Early life response to infection. Curr Opin Infect Dis 26:213-218

17. Iwasaki A, Medzhitov R (2015) Control of adaptive immunity by the innate immune system. Nat Immunol 16:343-353. https://doi. org/10.1038/ni.3123 